\title{
Effect of Azithromycin in treatment of cutaneous leishmaniasis
}

\section{Dindar S. Qurtas}

\section{ABSTRACT}

Introduction: Leishmaniasis is a vector born protozoal infection. Cutaneous leishmaniasis outbreak occurred during 2014 in Erbil governorate, Kurdistan-Iraq. First choice of its treatment is pentavalent antimony. Other options of treatment are available. Azithromycin is used as trial to be effective but human studies are lacking.

Patients and Methods: Prospective randomized open labeled interventional study conducted on 63 patients. The sample divided in to two groups. Group A received only intra-lesional sodium stibogluconate and the group B received combination therapy of intra-lesional sodium stibogluconate and azithromycin $500 \mathrm{mg}$ orally. Follow up done for lesions' healing at $6^{\text {th }}$ week and at the end of $8^{\text {th }}$ week of therapy.

Results: Nodular lesions were dominant morphology among the Lesions (71.5\%). Lesions mostly were ulcerated (59\%). Mean duration of lesions were $3 \pm 1.1$ and $2.4 \pm 1.8$ weeks in patients of group $A$ and $B$ respectively. At 6 th week in patients of group $A$, there were $13(41.9 \%)$ patients with complete healing of the lesions, while in group $B$ it was found in $23(71.8 \%)$ patients. At the end of $8^{\text {th }}$ week group $A$ patients showed complete healing in $21(67.7 \%)$ patients while in patients of group B complete healing found in 27(84.3\%).

Conclusions: Results of this study concludes that combination therapy of azithromycin and intra-lesional sodium stibogluconate provides more therapeutic effect if compared with the effect of intra-lesional sodium stibogluconate alone.

Key words: Cutaneous leishmaniasis, intra-lesional sodium stibogluconate, azithromycin

$$
\begin{aligned}
& \text { تأثير ازثرومايسين في علاج عدوى ليشمانيا الجلدية (حبة بغداد) } \\
& \text { المقدمة: عدوى اللشمانيا هو مرض طفيلي متوطن في الحشرات. شهدت مدينة اربيل -كردستان العراق انتشار وبائي لعدوى ليشمانيا الجلدية (حبة } \\
& \text { بغداد) في عام ع ا • r. العلاج الاساسي الاولي لهذه العدوى هو - بنتا فالنت انتيموني، خيارات اخرى لعلاج هذه العدوى ايضا متوفرة. المضاد } \\
& \text { الحيوي ازثرومايسين استخدم بحثيا كعلاج فعال لعدوى حبة بغداد الجلدية ولكن هذه البحوث تخلو من التجارب البشرية. } \\
& \text { خطة البحث: اجريت دراسة بحثية تداخلية مستقبلية عشوائية على با مريض. تم فرز العينة البحثية الى مجموعتين. المجموعة الاولى -استخدم في } \\
& \text { علاجها زرق ابر صوديم ستبوكلوكونيت بشكل مباشر داخل العدوى الجلدية فقط لا غير. المجموعة الثانية-استخدم في علاجها كل من زرق ابر } \\
& \text { صوديوم ستبوكلوكونيت المباشرة بالإضافة الى استخدام المضاد الحيوي ازثرومايسين كعلاج مرافق وبجرعه . . ه ملفم حبوب فموية. تم متابعه المسار } \\
& \text { العلاجي للعدوى الجلدية خلال الاسبوع السادس وفي نهاية الاسبوع الثامن من العلاج. }
\end{aligned}
$$

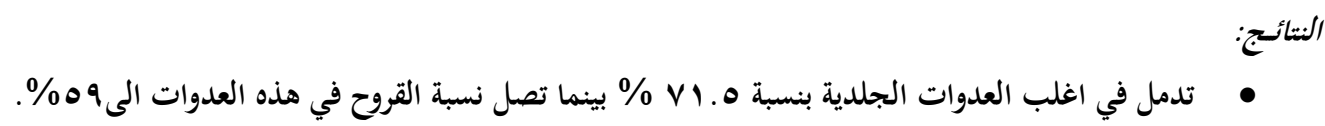

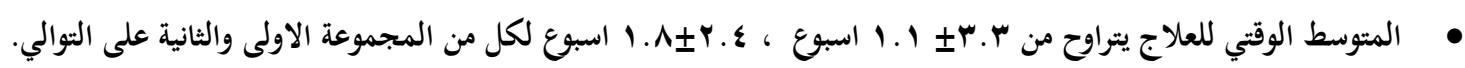

$$
\begin{aligned}
& \text { • الاسبوع السادس من المجموعة الاولى يصل عدد المرضى الذين تم شفائهم بشكل كامل من العدوى الجلدية الى با مريض (نسبة }
\end{aligned}
$$

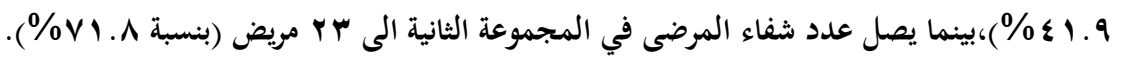




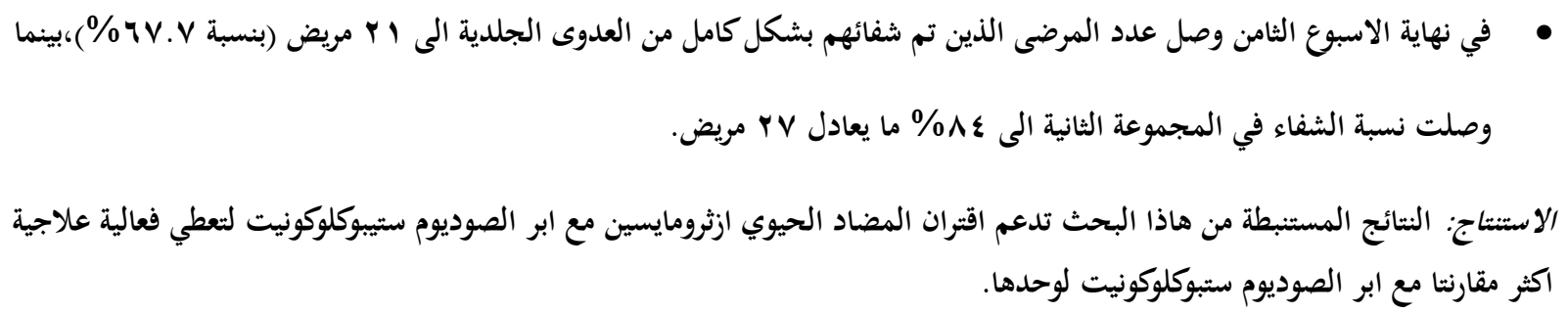

\section{INTRODUCTION}

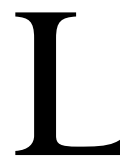

eishmaniasis is parasitic infection caused by Leishmania species and transmitted to human by sand-fly vector. ${ }^{[1]}$ Cutaneous leishmaniasis (CL) is an endemic infection in Iraq. ${ }^{[2,3]}$ Its outbreak in Erbil governorate happened in $2015{ }^{[4]}$ This skin disease is self-limited but its course may prolong for one year or more. ${ }^{[5,6]}$ Also this disease could have negative impact on various aspects of the patients as physical, psychological, social and economic. ${ }^{[7,9]}$ Skin lesions usually appear weeks to months after insect bite as papules, plaques and nodules. These lesion indurate, crusts, ulcerate accordingly. ${ }^{[8]}$ The last healing residua usually is disfiguring scar. ${ }^{[9]}$ Treatment of CL with pentavalent antimony, especially sodium stibogluconate SSG (pentostam) intra-lesionally for non-disseminated cases was successfully used. $^{[10]}$ Other drugs like azoles, rifampicin, metronidazole, paromomycin etc. are used for its treatment, but still SSG remains the first line of the treatment of CL despite its side effects and cost. ${ }^{[10-12]}$ Many studies were conducted to optimize treatment of CL because resistant cases to the above mentioned treatments are going to grow up. ${ }^{[13,14]}$ Bacterial super-infection to lesions of $\mathrm{CL}$ is considered to be one of the complications of this disease which is incriminated to be the cause of the resistant cases to proven therapy. So that combating this super-infection is thought to be very helpful to reduce the possibility of resistance and better response to the treatment plan. ${ }^{[15]}$ Macrolides especially azithromycin and clarithromycin had been studied to be effective against Leishmania species of old world, but these studies were not conducted on the lesions of human being. ${ }^{[16-18]}$ Azithromycin due to its property of achieving high concentration in macrophages is promising in treatment of lesions of CL. ${ }^{[18.19]}$ In Erbil governorate after the outbreak of CL we tried conduct this study to compare combination therapy of azithromycin and SSG intralesionally to SSG intra-lesionally alone as monotherapy.

\section{PATIENTS AND METHODS}

Prospective open labeled randomized controlled study conducted from September 2016 up to March 2017 in "Erbil Dermatology Teaching Center" in Erbil, Kurdistan, Iraq. Sixty three patients with cutaneous leishmaniasis were assigned to be included in this study. Patients were diagnosed clinically by two separate dermatologists and then confirmed parasitologically through detection of Donovan's bodies in the smears taken from patients' lesions. The study sample randomly divided into 2 groups; the patients randomized by block randomization method through possible balanced combinations with 2 patients to treatment group and the following 2 patients to control group. The first group A were 31 patients received intral-lesional (IL) sodium stibogluconate only, $0.5-1 \mathrm{ml}$ per each lesion and the session repeated after 2 weeks, the second group B were 32 patients received intralesional sodium stibogluconate in the same dosage and frequency as in group A and oral azithromycin tablet $500 \mathrm{mg}$ three successive days per week for up to 2 months. Patients were controlled for the clinical improvement at two follow up points. First follow up point was $6^{\text {th }}$ week from start of the treatment and the second control was at the end of $8^{\text {th }}$ week of therapy (Figure-1). On both follow up point size of induration and photography of the lesions were 
taken. Response scaled as complete healing, very good response, good response and poor response when there was reduction in the size of induration of lesions in 100\%, 75\%-99\%, 25\%-
$74 \%$ and less than $25 \%$ respectively. Statistical analysis of the data done by using the software SPSS program version 22.

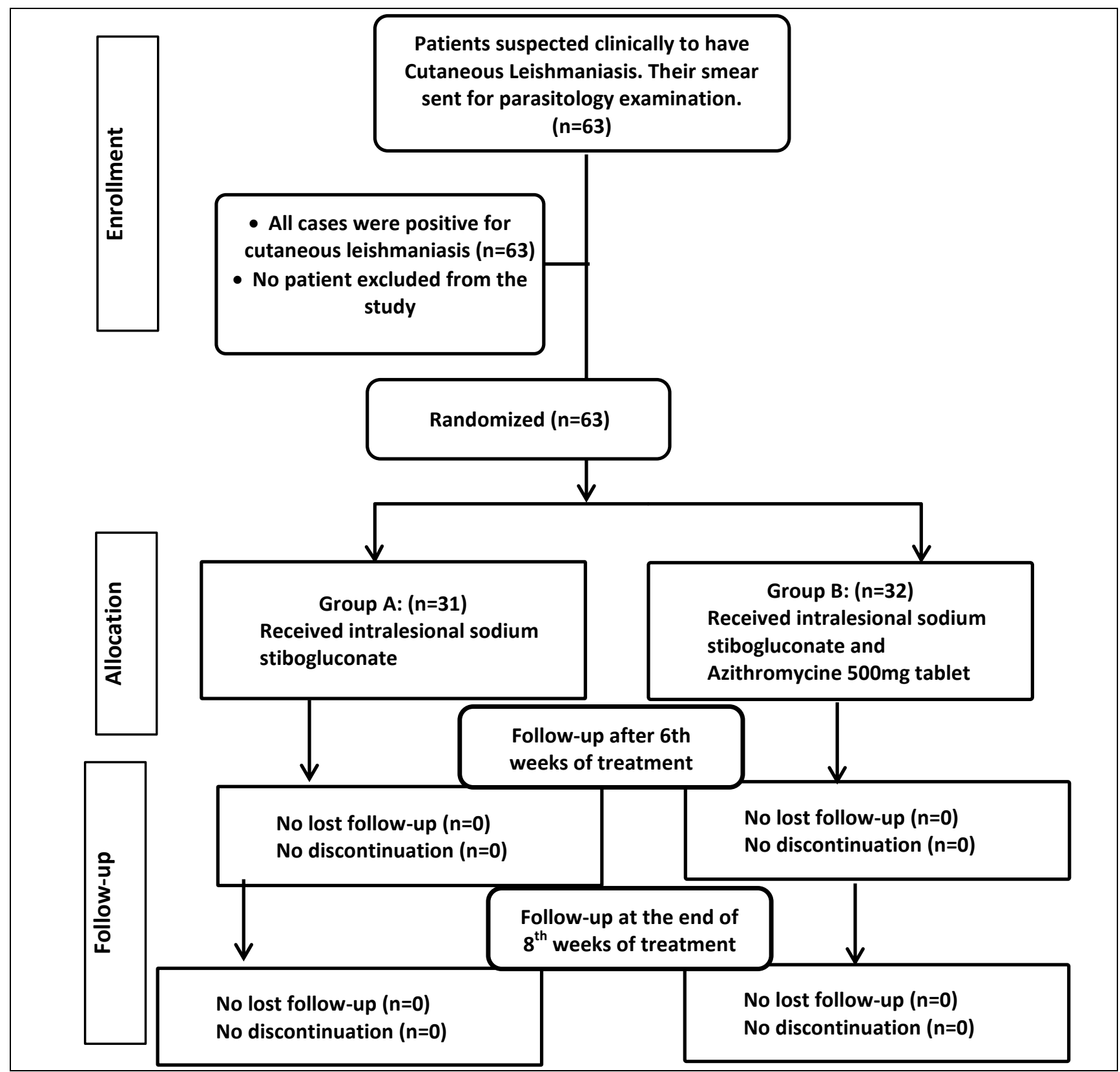

Fig 1. Study flowchart according consort stands 


\section{RESULTS}

Total 63 patients suffering from cutaneous leishmaniasis included in this study. Among them 49 were males and 14 were females. The age ranged between 7-64 years, the mean of 35

\pm 10.4 years. There were no difference between mean ages of both group $\mathrm{A}$ and $\mathrm{B}(\mathrm{P}>0.05)$. (Table-1).

Table 1. Main characteristics of patients in both groups.

\begin{tabular}{||c|c|c||}
\hline \hline Characteristic & $\begin{array}{c}\text { Group a (SSG) } \\
N=31\end{array}$ & $\begin{array}{c}\text { Group b (SSG + azithromycin) } \\
N=32\end{array}$ \\
\hline Age / years* & $32 \pm 8.2$ & $37 \pm 7.4$ \\
\hline Sex & Male 23, Female 8 & Male 26, Female 6 \\
\hline Number of lesions* & $9 \pm 2.3$ & $\mathbf{8} \pm 3.1$ \\
\hline Duration of lesions / weeks* & $3 \pm 1.1$ & $2.4 \pm 1.8$ \\
\hline Size of lesions / mm* & $3.1 \pm 0.6$ & $2.8 \pm 0.4$ \\
\hline$*$ P value $>0.05$ & \multicolumn{2}{|l||}{} \\
\hline
\end{tabular}

Majority of the lesions in this sample were nodular $(71.5 \%)$. Ulceration was dominant characteristic of the lesions found in $59 \%$ of the lesions (Table-2). The duration of the lesions at the time of presentation was ranged between 3 and 9 weeks, mean of $3 \pm 1.1$ and $2.4 \pm 1.8$ weeks in patients of group A and B respectively. The difference between both group number of lesions and their durations was not found $(\mathrm{P}>$ 0.05). (Table-1). Commonest site of lesions were foot, forearms, hands, face and legs, $23 \%$, $20 \%, 17 \%$ and $15 \%$ respectively. (Figure-2).

Table 2. Type of cl lesions and their ulceration

\begin{tabular}{||c|c|c|c||}
\hline \multirow{2}{*}{ Type of lesions } & \multirow{2}{*}{ Number of lesions } & \multicolumn{2}{|c|}{ Ulceration } \\
\cline { 3 - 4 } & & Yes & No \\
\hline Papule & $17(10.8 \%)$ & $1(5.8 \%)$ & $16(94.2 \%)$ \\
\hline Patch & $28(17.7 \%)$ & $25(89.2 \%)$ & $3(10.8 \%)$ \\
\hline Nodule & $113(71.5 \%)$ & $68(60.1 \%)$ & $45(39.9 \%)$ \\
\hline Total & 158 & $94(59.5 \%)$ & $64(40.5 \%)$ \\
\hline
\end{tabular}

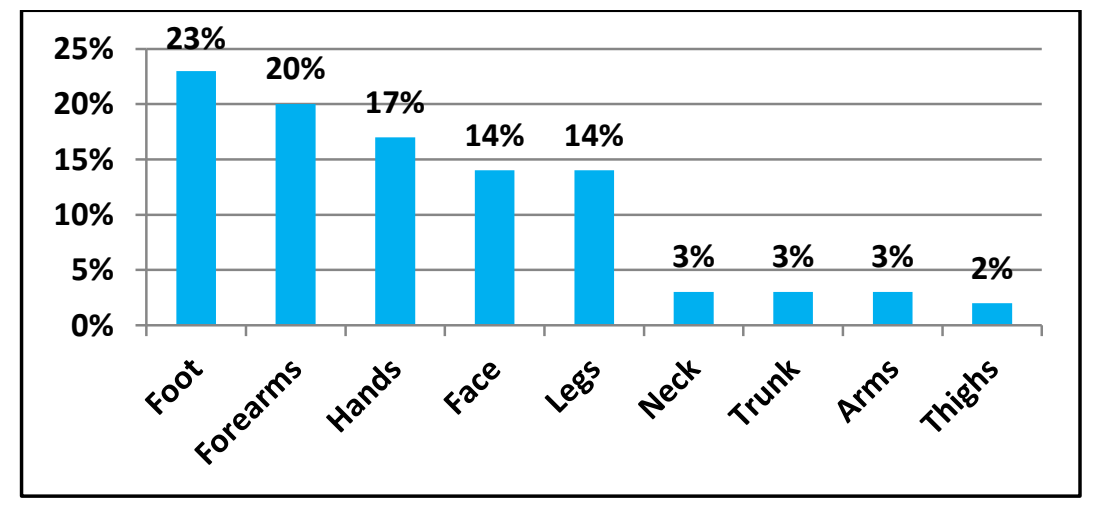

Fig 2. Distribution of lesions over body anatomic areas 
At $6^{\text {th }}$ week follow up: in group A complete healing of the lesions was found in $13(41.9 \%)$ patients and very good response found in $8(25.8 \%)$ patients. In group B complete healing was found in $23(71.8 \%)$ patients and very good response was found in 6(18.7\%). (Table-3). At the end of $8^{\text {th }}$ week in group A complete healing of the lesions was increased and number of patients become $21(67.7 \%)$ patients while in patients of group B complete healing found in 27(84.3\%). (Table-3).

Table 3. Response of the patients in both group in both $6^{\text {th }}$ week of therapy and after 8 weeks of therapy

\begin{tabular}{|c|c|c|c|c|}
\hline \multirow[b]{2}{*}{ Follow up } & \multicolumn{2}{|c|}{$6^{\text {th }}$ week } & \multicolumn{2}{|c|}{ End of $8^{\text {th }}$ week } \\
\hline & Gr. $A(N=31)$ & $G r . B(N=32)$ & Gr. $A(N=31)$ & Gr. $B(N=32)$ \\
\hline Poor Response & $7(22.5 \%)$ & $2(6.3 \%)$ & $3(9.7 \%)$ & $0(0 \%)$ \\
\hline Good response & $3(9.8 \%)$ & $1(3.1 \%)$ & $1(3.2 \%)$ & $2(6.3 \%)$ \\
\hline Very good response & $8(25.8)$ & $6(18.7 \%)$ & $6(19.4 \%)$ & $3(9.4 \%)$ \\
\hline Complete healing & $13(41.9)$ & $23(71.8 \%)$ & $21(67.7 \%)$ & $27(84.3 \%)$ \\
\hline $\begin{array}{c}\text { Total } \\
\end{array}$ & 31 & 32 & 31 & 32 \\
\hline
\end{tabular}

During the course of therapy no significant side effects of drugs had been observed apart from pain during intra-lesional injections in all patients, gastric upset in 3 patients and dizziness in 1 patient in the patients group receiving azithromycin orally in combination to IL sodium stibogluconate, while in patients receiving only IL sodium stibogluconate no such adverse effects seen apart from pain during intra-lesional injections.

\section{DISCUSSION}

Cutaneous leishmaniasis it is the parasitic infection that have different treatment options but no one was found to have satisfactory for both clinician and patient, in which resistance to treatment is the main problem that face therapy introduction. ${ }^{[20,21]}$ Sodium stibogluconate still is the treatment number one in management of CL in Iraq but emergence of difficult cases make to think about alternative ways of treatment. ${ }^{[20]}$ In this study we tried to augment the effect of sodium stibogluconate by its combination with azithromycin orally. We observed that earlier resolution of the condition could be found in a very good proportion of the patients, at $6^{\text {th }}$ week of therapy when IL sodium stibogluconate combined with oral azithromycin $71.8 \%$ of patients while in cases of monotherapy with IL sodium stibogluconate was only in $41.9 \%$ of the patients $(\mathrm{P}<0.001)$. Azithromycin has antiprotozoal and antileishmanial effect, ${ }^{[16,17]}$ Eglal and coauthors tried oral azithromycin in combination with multifosine for the treatment of Leishmania major infection in mice, they proved the effectiveness of this drug. ${ }^{[18]}$ Secondary bacterial infection of CL lesions in some case could complicate course of the disease. ${ }^{[18.21]}$ So that the synergistic effect of both azithromycin and sodium stibogluconate could be due to the antibacterial effect of azithromycin which can eliminate secondary bacterial infection of the lesions. In our study there were some cases that did not healed after 8 weeks therapy in patients receiving IL SSG (poor response $9.7 \%$ and good response 3.2\%). This proportion could be due to strains that not respond to this treatment, as recently in some countries identification of species carried because drug and treatment plan is species directed. ${ }^{[22]}$ We can conclude that further studies to be conducted to see the effect of these combination therapy on different species of CL in Iraq to identify the species which is sensitive to the suggest treatment. These need to provide identification of Leishmania species in all case 
of CL before the introduction of therapy which will provide more cost and time effective therapy; also it will reduce probability of nonresponding cases. According to the results of this study we conclude that oral azithromycin in combination with IL sodium stibogluconate can achieve earlier healing of the lesion and less possibility of resistant cases.

\section{REFERENCES}

1. Alsamarai AM, Alobaidi HS. Cutaneous Leishmaniasis in Iraq. J infect in develop count. 2009; 3: 123-129.

2. Alvar J, V élez ID, Bern C. Leishmaniasis Worldwide and Global Estimates of Its Incidence. PLoS One. 2012; 7: 35671.

3. WHO. Country Cooperation Strategy for WHO and Iraq, 2012-2017. World Health Organization, Regional Office for the Eastern Mediterranean, WHO 2013; 1-52.

4. Abdulla QB. Factors associated with the outbreak of cutaneous leishmaniasis in Erbil governorate in 2015. KBMS dissertation. Kurdistan board for medical specialties. Iraq; 2017.

5. Bolognia JL, Jorizzo JL, Schaffer JV. Dermatology. Third edition. Elsevier Limited. 2012: 1360-1378.

6. Goldsmith L, Katz S, Gilchrest B. Fitzpatrick's Dermatology in General Medicine, $8^{\text {th }}$ edition. McGrow-Hill. 2008: 2001-2010.

7. Reedijk SH, Schallig HD. Cutaneous leishmaniasis: recent developments in diagnosis and management. 2015; 16:99-109.

8. Piscopo TV and Azzopardi CM. Leishmaniasis. Post-grad Med J. 2007. 83: 649-657

9. Bennis $I$, Severine $T$, Filali $H$, Brouwere VD, Shihabi H, Boelaert M. Psychosocial impact of scars due to cutaneous leishmaniasis on high school students in Errachidia province, Morocco. Infect Dis of Pover J. 2017; 6: 44-53.

10. Brito NC, Rabello A, Cota GF. Efficacy of pentavalent antimoniate intralesional infiltration therapy for cutaneous leishmaniasis: A systematic review. PLoS ONE. 2017; 9: e0184777.

11. Salah AB, Messaoud NB, Guedri E. Topical Paromomycin for Cutaneous Leishmaniasis. N Eng J Med. 2013. 6: 524-532.

12. Khatami A, Firooz A, Gorouhi F, and Dowlati Y. Treatment of acute old world cutaneous leishmaniasis: A systematic review of the randomized controlled trials. J Am Acad Dermatol. 2007; 57: 335.e1-335.e29.

13. Arevalo I, Ward B, Miller R, Meng T. Successful treatment of drug-resistant cutaneous Leishmaniasis in humans by Use of Imiquimod, an Immunomodulator. Clini Infect Dis. 2001. 33:1847-1851.

14. Al-Natour SH. Update in the treatment of cutaneous leishmaniasis. J Family Comm Med. 2009; 16: 41-47.

15. Doudi M, Setorki M, Narimani M. Bacterial super infection in Zoonotic Cutaneous Leishmaniasis. Medical Science Monitor. 2012; 9: 356-361.

16. Prata A, Silva-Vergara ML, Costa L. Efficacy of azithromycin in the treatment of cutaneous leishmaniasis. Revista da Sociedade Brasileira de Medicina Tropical. 2003; 1:65-69

17. Sazgarnia A, Zabolinejad N, Layegh P, Rajabi O, Berenji F, Javidi Z, Salari R. Antileishmanial Activity of Liposomal Clarithromycin against Leishmania Major Promastigotes. Iranian Journal of Basic Medical Sciences. 2011; 6:12101214

18. Amer EI, Eissa MM, Mossallam SF. Oral azithromycin versus its combination with miltefosine for the treatment of experimental Old World cutaneous leishmaniasis. J Parasit Dis. 2016; 2: 475-484.

19. Oliveira-Silva F, Morais-Teixeira E, Rabello A. Antileishmanial Activity of Azithromycin Against Leishmania (Leishmania) amazonensis, Leishmania (Viannia) braziliensis, and Leishmania (Leishmania) chagasi. Am. J. Trop. Med. Hyg. 2008; 5: 745-749

20. Control of the leishmaniases: WHO technical report series no. 949. Geneva: World Health Organization, 2010.

21. Simon L. Croft1, Sundar S, Fairlamb AH. Drug Resistance in Leishmaniasis. Clin. Microbiol. Rev. 2006; 1: 111-126.

22. Hodiamont CJ, Kager PA, Bart A. SpeciesDirected Therapy for Leishmaniasis in Returning Travellers: A Comprehensive Guide. PLoS neglected tropical diseases. 2014; 5: e2832. 